\title{
Primary Malignant Melanoma of the Bladder: A Rare Case Report in Asia and Review of the Literature
}

\section{Tanan Bejrananda \\ Anupong Sawasdee \\ Sarayuth Boonchai (D) \\ Monthira Tanthanuch}

Division of Urology, Department of Surgery, Faculty of Medicine, Prince of Songkla University, Hatyai, Songkhla, Thailand
Correspondence: Tanan Bejrananda Division of Urology, Department of Surgery, Faculty of Medicine, Prince of Songkla University, Hatyai, Songkhla, Thailand

Tel +660-81608I880

Email t|3ers@hotmail.com
Background: Primary malignant melanoma (PMM) of the bladder is extremely rare and has a poor prognosis; just 40 cases of PMM of the bladder have been recorded in the literature. We described a case of PMM of the bladder, treatment, and a review of the literature because the recommended treatment choices are not widely known.

Case Presentation: An 80-year-old Thai female came in with a three-month history of pelvic pain and dysuria without extensive hematuria. She underwent transurethral excision of the bladder tumor and histologically reported malignant melanoma with no further primary sites of melanoma after computed tomography indicated a big heterogeneous enhancing mass on the posterior wall of the bladder. The patient eventually underwent anterior pelvic exenteration with ileal conduit, but metastatic disease occurred one year later.

Conclusion: Bladder melanoma has a fatal aggressive nature. Certain diagnostic features can be obtained through histopathological investigation, immunohistochemistry, clinical history, and endoscopic evaluation. Despite a wide range of treatments, people with PMM still have a bad prognosis.

Keywords: primary malignant melanoma, rare bladder tumor, extracutaneous melanoma, radical cystectomy

\section{Introduction}

Primary malignant melanoma (PMM) of the bladder is extremely rare and has a poor prognosis; just 40 cases of PMM of the bladder have been recorded in the literature. We described a case of PMM of the bladder, treatment, and a review of the literature because the recommended treatment choices are not widely known.

\section{Case Presentation}

An 80-year-old Thai female was presented with pelvic pain and dysuria without gross hematuria for 3 months. After medical history and complete physical examination were obtained. CT abdomen was done and revealed a large heterogeneous enhancing mass $5.3 \times 6.2 \mathrm{~cm}$ in size with internal calcification in the urinary bladder (Figure 1). Cystoscopy revealed a large necrotic mass that could not be identified as the ureteric orifice or the bladder base and a transurethral resection of the bladder tumor was performed. The pathological report revealed malignant melanoma spindle cell variant. Hematoxylin and eosin (H\&E) staining was performed on tissue sections and S100 (+), HMB-45 (+), and Melan-A $(+)$ were detected by immunohistochemistry (Figure 2). Complete investigations were performed to exclude other primary sites of melanoma. Dermatologic, otorhinolaryngologic, ophthalmologic 

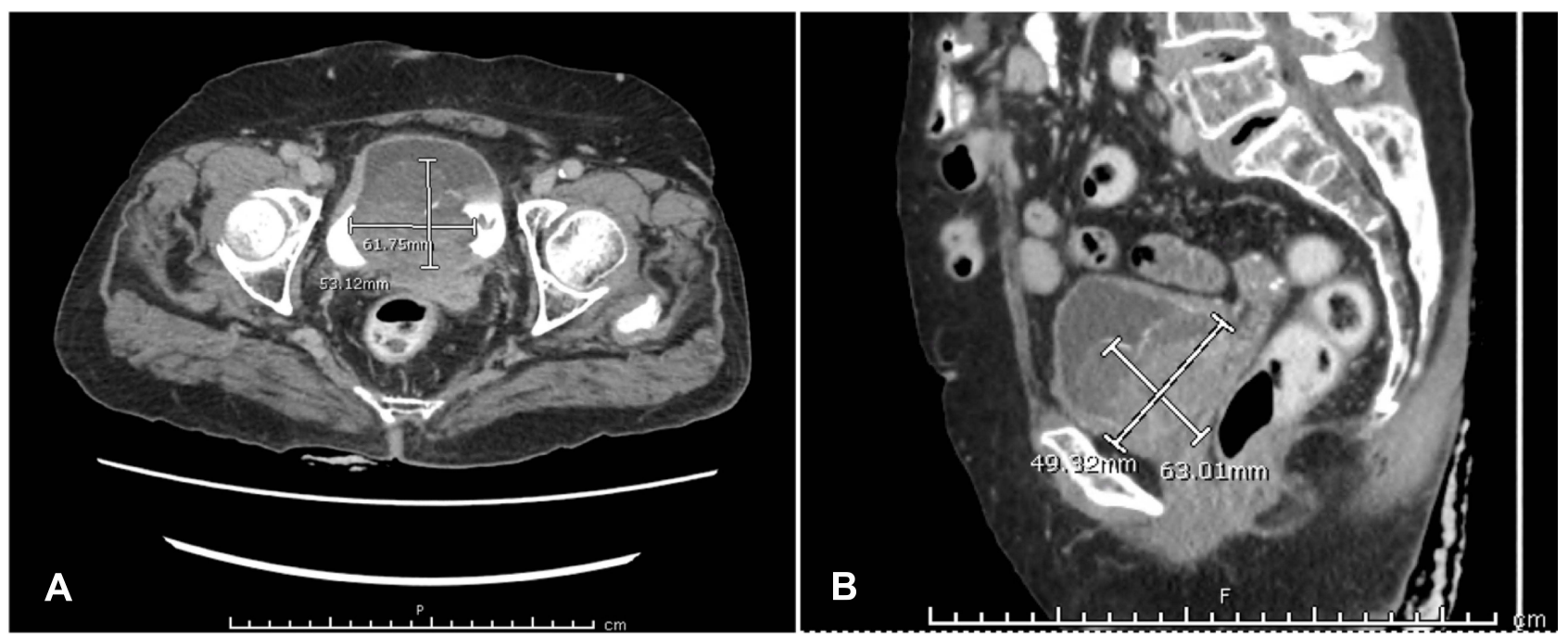

Figure I Axial (A) and sagittal (B) CT scans of the whole abdomen included the pelvis with IV contrast injection demonstrated a large heterogenous enhancing mass, $5.3 \times 6.2 \mathrm{~cm}$ in size with internal calcification in the urinary bladder.

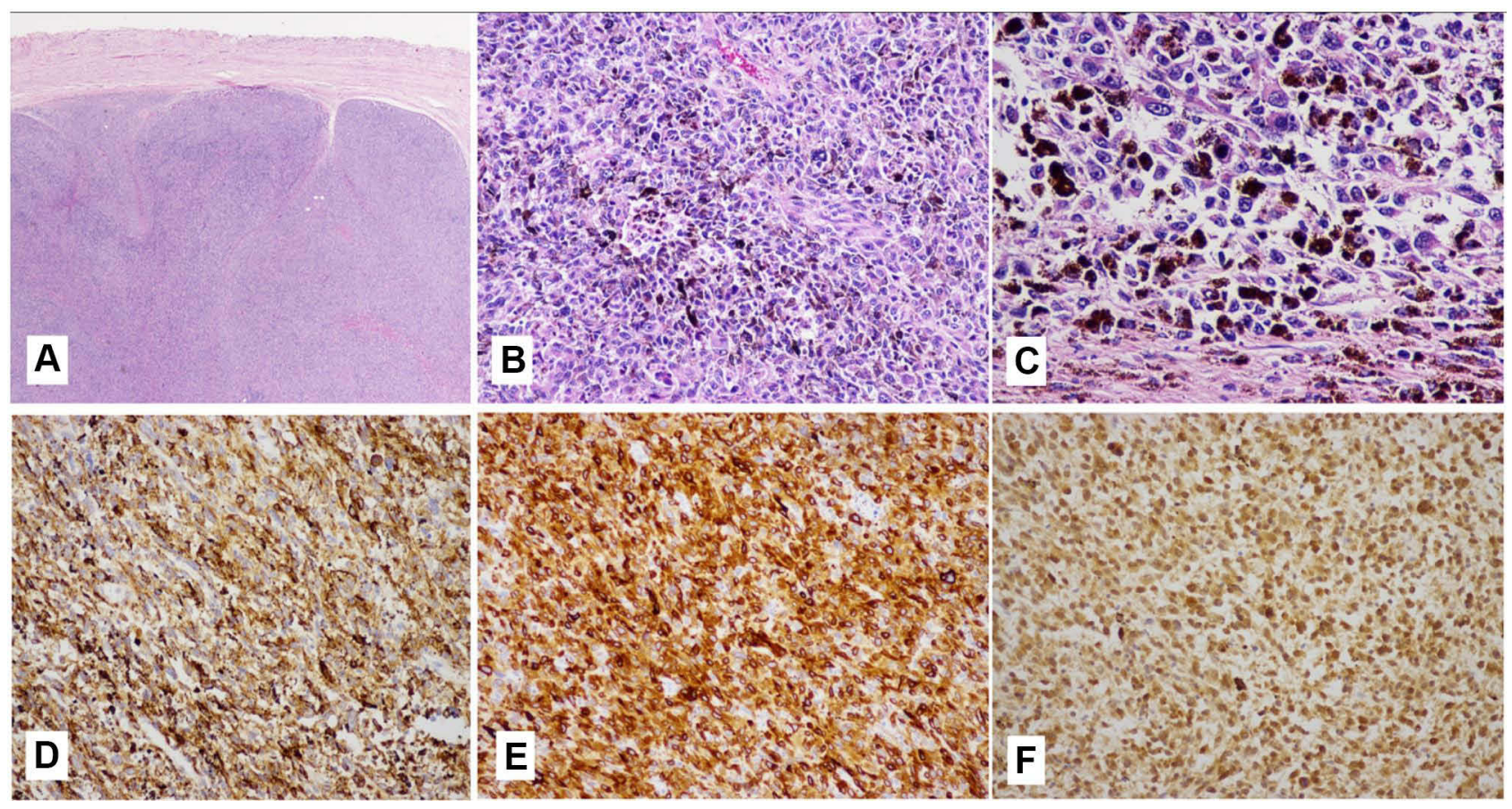

Figure 2 The histological appearance of the urinary bladder melanoma tissue was composed of solid nests and groups of atypical, poorly differentiated, highly mitotically active cells with prominent nucleoli: $\mathrm{HE} \times 10$ (A); HE xI00 (B); HE x400 (C); immunohistochemistry indicating positive reaction to HMB-45 (xI00) (D); Melan-A(xI00) (E) and S-100 (x100) (F).

and proctologic examinations were unremarkable, and upper gastrointestinal endoscopy and colonoscopy were performed and showed normal findings. Computed tomography (CT) scans of the abdomen, chest, brain and bone scans found no metastasis or other suspected primary lesions. Primary malignant melanoma of the bladder was diagnosed, and a multidisciplinary team approach suggested no further adjuvant therapy was needed because of the patient's age, comorbidity and poor prognosis despite treatment. The patient agreed to take the risk and had an anterior pelvic exenteration with an ileal conduit performed. The pathology revealed malignant melanoma and invasion of the bladder serosa's posterior wall, but all resection margins of the pelvic lymph nodes were negative 
for metastasis. After a postoperative period of one year, a computerized tomography scan showed new cardiophrenic lymph node enlargement without local recurrence (Figure 3). Tissue biopsy was performed and reported for metastasis malignant melanoma. The patient refused a metastasectomy and thus missed the follow-up.

\section{Discussion and Conclusions}

Primary malignant melanoma is very rare in the genitourinary tract, and extremely rare in the bladder. We reported a case of PMM of the bladder, with previously reported 39 cases worldwide as in Table 1. The most common presenting symptom is hematuria. The diagnosis of bladder malignant melanoma requires cystoscopy and tissue biopsy. Cystoscopy revealed a dark pigmented tumor. ${ }^{1,2}$ Melanoma-like features such as melanin pigment, nests of pleomorphic cells with macronuclei, and prominent nucleoli were observed during the pathologic examination. Typically, immunohistochemical evaluations demonstrate positivity for S-100, HMB-45, MART-1/Melan-A, Tyrosinase and MITF. $^{7}$ A patient history and physical examination of the skin and were also evaluated for visceral primary sites to distinguish primary from secondary melanomas of the bladder comprehensively. ${ }^{5}$

In 1976, Ainsworth established the correct definition of bladder melanoma, including careful physical examination, including the skin with Wood's light, together with a detailed history to exclude cutaneous melanoma, pattern of recurrence consistent with primary melanoma of the urinary bladder, histologically proved primary atypical melanocytes and also, especially, exclusion of visceral melanoma following complete evaluation. ${ }^{8}$ Malignant melanoma's histogenesis in the urinary tract, particularly in the bladder, is unknown. There are currently two theories: one supports the idea that melanoblasts migrate from the neural cusps into the mesenchyme during embryogenesis, but they can also migrate to ectopic places, such as the developing urinary tract, where they remain inactive for a long time before transforming into malignant cells under the influence of some local factors. Another theory is that urothelial cells produced from urothelial stem cells may develop into malignant melanocytes. ${ }^{4}$ Transurethral resection of a bladder tumor, partial or radical cystectomy, radiotherapy, chemotherapy and immunotherapy are the treatment options. However, initial treatment for organconfined tumors involves surgery for both partial and radical cystectomy with lymph node resection. If there are contraindications for surgery, chemotherapy for systemic therapy is not proper, and radiotherapy and immunotherapy with interferon- $\alpha$ can be administered.

Overall, reports of the treatment outcomes of patients with this tumor are still poor, despite the variety of therapies available. Most patients die due to widespread metastases within 3 years after the initial diagnosis. ${ }^{5,9,10}$ This was the case for our patient, who was diagnosed at a localized stage and received anterior pelvic exenteration, but still developed a metastatic disease within 1 year after
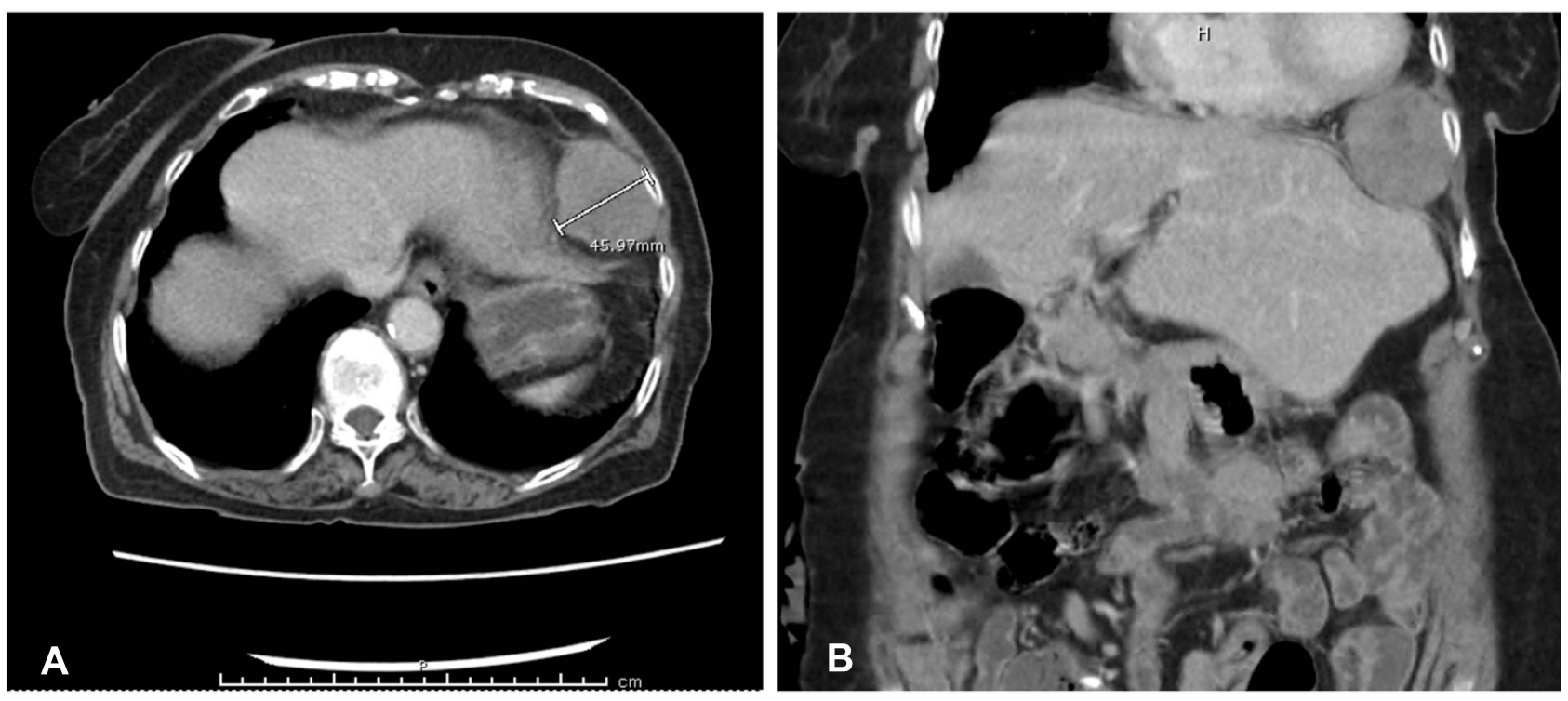

Figure 3 Axial (A) and coronal (B) CT scan of the abdomen/pelvis with IV contrast injection, demonstrated a new left cardiophrenic lymph node enlargement. 


\begin{tabular}{|c|c|c|c|c|c|c|c|c|c|c|c|c|c|c|c|c|c|c|c|c|c|c|c|c|}
\hline 总 & 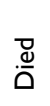 & 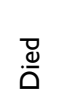 & $\stackrel{0}{\stackrel{0}{*}}$ & 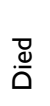 & ס्ष्ठ & $\stackrel{0}{\stackrel{0}{<}}$ & סֶ. & 总 & $\stackrel{0}{\stackrel{0}{<}}$ & $\frac{\alpha}{z}$ & 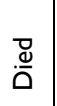 & 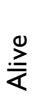 & 总 & 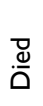 & $\stackrel{0}{\stackrel{0}{\longleftarrow}}$ & 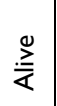 & 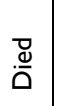 & $\frac{\mathscr{\Xi}}{\mathscr{0}}$ & 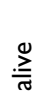 & 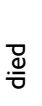 & 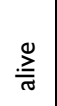 & 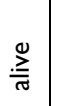 & סֶ.ّ & $\stackrel{0}{\stackrel{0}{*}}$ \\
\hline 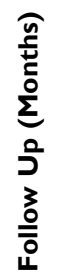 & $\stackrel{\text { m }}{ }$ & $N$ & $\simeq$ & $\stackrel{m}{m}$ & $\simeq$ & $m$ & $\infty$ & $n$ & 0 & 管 & $\stackrel{ \pm}{\sim}$ & $\underline{\underline{n}}$ & $\underline{\infty}$ & $m$ & $\simeq$ & $\underline{\infty}$ & 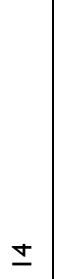 & $\infty$ & $\underset{J}{J}$ & $\underline{0}$ & $\underline{\bullet}$ & 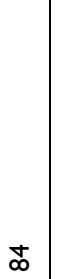 & $\sigma$ & 으 \\
\hline
\end{tabular}

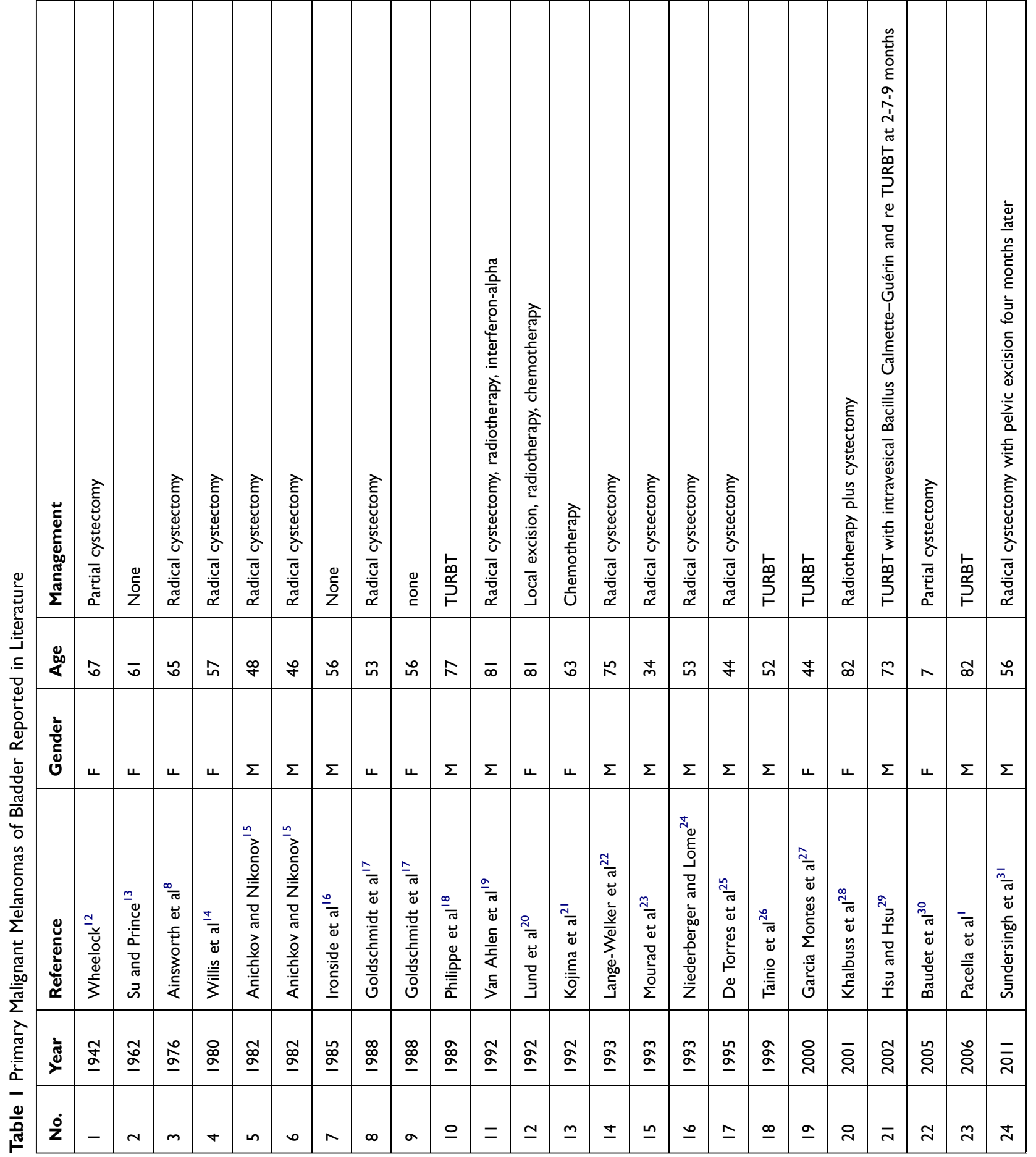




\begin{tabular}{|c|c|c|c|c|c|c|c|c|c|c|c|c|c|c|c|}
\hline$\stackrel{\circlearrowright}{\ddot{\Delta}}$ & $\stackrel{o}{z}$ & .ֶ. & 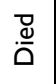 & 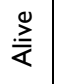 & $\stackrel{\varpi}{\ddot{0}}$ & 受 & 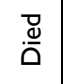 & 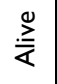 & $\stackrel{\Xi}{.}$ & $\stackrel{\ddot{\omega}}{\overline{0}}$ & 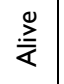 & 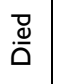 & 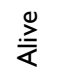 & $\stackrel{\bullet}{\circ}$ & 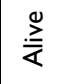 \\
\hline in & 兴 & N & $\frac{\alpha}{z}$ & $\simeq$ & $\underline{\infty}$ & $\stackrel{\alpha}{Z}$ & $\sigma$ & 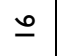 & o & $\stackrel{\text { Ln }}{0}$ & $\stackrel{ \pm}{\sim}$ & $\stackrel{n}{\underline{n}}$ & o & \pm & $\simeq$ \\
\hline 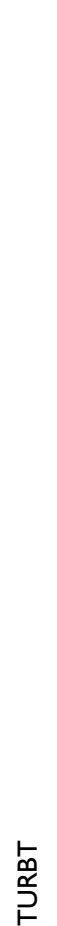 & 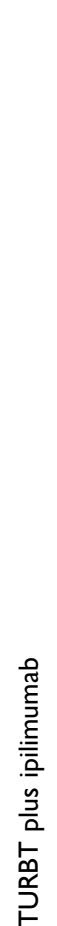 & 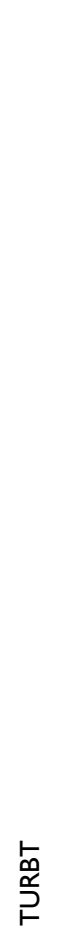 & $\stackrel{\circ}{z}$ & 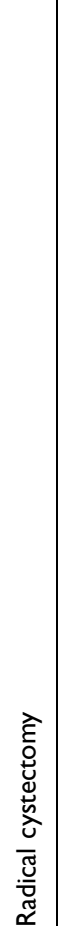 & 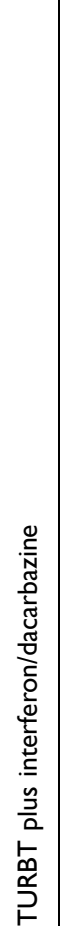 & 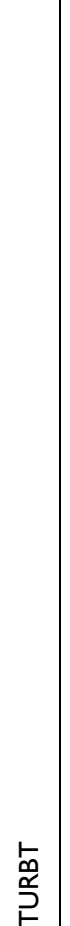 & 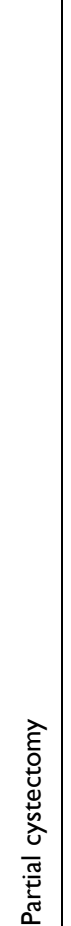 & 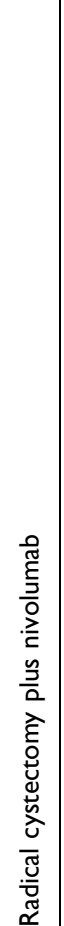 & 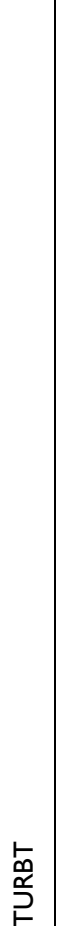 & $\begin{array}{l}\stackrel{5}{\underline{\omega}} \\
\stackrel{2}{2}\end{array}$ & 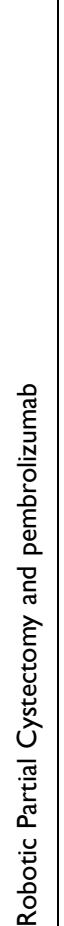 & 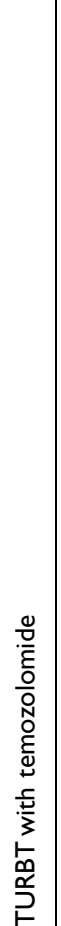 & 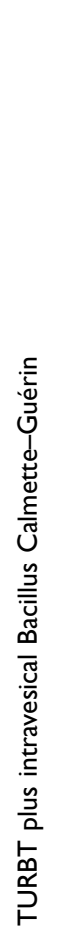 & 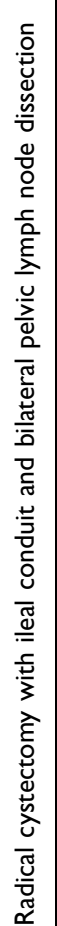 & 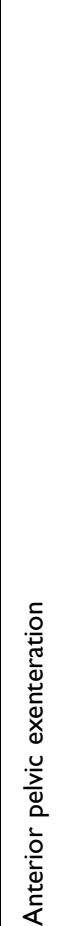 \\
\hline $\bar{\lambda}$ & 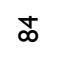 & R & $\stackrel{\infty}{\wedge}$ & $\bar{\infty}$ & กี & $\bar{\infty}$ & $\stackrel{\infty}{n}$ & $N$ & $\infty$ & $\hat{\infty}$ & $\hat{\lambda}$ & $\dot{m}$ & $\stackrel{+}{N}$ & $\stackrel{\infty}{\wedge}$ & $\infty$ \\
\hline$\Sigma$ & ᄂ & $\Sigma$ & $\Sigma$ & $\Sigma$ & $\Sigma$ & $\Sigma$ & $\Sigma$ & $\Sigma$ & $\Sigma$ & $\Sigma$ & ч & ч & $\Sigma$ & ч & ч \\
\hline 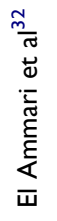 & 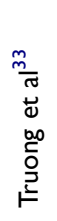 & 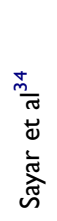 & 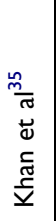 & 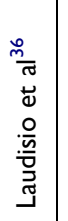 & $\begin{array}{l}\frac{\hat{m}}{\bar{J}} \\
\stackrel{\Delta}{0} \\
\stackrel{0}{\Delta} \\
0\end{array}$ & 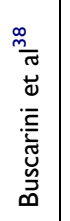 & 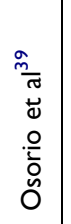 & 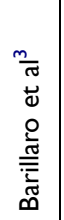 & 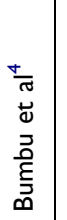 & 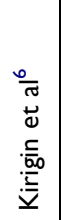 & 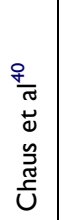 & 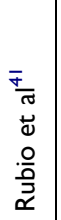 & 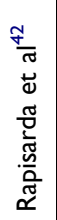 & 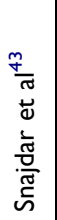 & 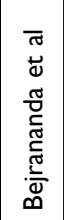 \\
\hline$\overline{\bar{i}}$ & $\frac{m}{i}$ & $\frac{\nabla}{i}$ & $\stackrel{\circ}{\circ}$ & $\stackrel{\circ}{\circ}$ & $\overline{\bar{N}}$ & $\overline{\bar{N}}$ & $\frac{\infty}{2}$ & $\stackrel{\infty}{\grave{N}}$ & $\frac{\sigma}{\bar{N}}$ & $\frac{\sigma}{\bar{N}}$ & $\stackrel{\circ}{\bar{\sim}}$ & ठ্ণ & $\overline{\text { ડ̦ }}$ & $\overline{\tilde{N}}$ & $\overline{\mathrm{S}}$ \\
\hline$\stackrel{\sim}{\sim}$ & $\stackrel{\sim}{\sim}$ & $\hat{\lambda}$ & $\stackrel{\infty}{\sim}$ & ๙े & 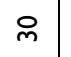 & $\bar{m}$ & $\tilde{m}$ & $m$ & $\dot{m}$ & $\stackrel{\stackrel{\mu}{m}}{n}$ & $\stackrel{\infty}{m}$ & $\hat{m}$ & $\stackrel{\infty}{m}$ & $\dot{m}$ & o \\
\hline
\end{tabular}


treatment. According to a literature review, PMM of the bladder has a poor prognosis for many reasons, advanced stage as presenting symptom, difficult to diagnose by confirmed pathology and aggressiveness, with two-thirds of patients developing metastatic disease within three years. ${ }^{5,6}$ In addition, there is a lack of data suggesting the best treatment options. It appears that tumor stage and mitotic activity can help in prognosis and some authors suggest that identifying if the malignancy contains a BRAF-activating mutation for therapeutic targeting may be of benefit ${ }^{4,5}$ and previous report of BRAF mutations has shown in melanoma about $60 \%$ of cases. ${ }^{11}$ Others have suggested immunotherapy after a radical cystectomy with nivolumab as a successful treatment. ${ }^{3}$

In conclusion, primary malignant melanoma of the bladder is a very rare disease. Complete investigation to distinguish primary from secondary disease is very important. The choice of treatments should be based on overall prognosis, the patient's factors and aggressiveness if disease. Despite the variety of therapies, the prognosis of patients with this tumor is still poor. However, local control with aggressive surgery has still shown benefits in survival.

\section{Abbreviations}

PMM, primary malignant of melanoma; TURB, transurethral resection of bladder tumor; CT, computerized tomography; cm, centimeters; BRAF, b-raf protooncogene; MITF, Microphthalmia transcription factor.

\section{Data Sharing Statement}

All data generated or analysed during this study are included in this published article.

\section{Ethics Approval and Consent to Participate}

This study was approved by the ethical committee of Songklanagarind hospital, Faculty of Medicine, Prince of Songkla University, Hat Yai, Thailand.

Written informed consent was obtained from the patient for publication of this case report and any accompanying images. A copy of the written consent is available for review.

\section{Acknowledgments}

This work was supported by all patient care teams in the Division of Urology, Department of Surgery, Songklanagarind hospital, Prince of Songkla University.

\section{Author Contributions}

All authors made a significant contribution to the work reported, whether that is in the conception, study design, execution, acquisition of data, analysis and interpretation, or in all these areas; took part in drafting, revising or critically reviewing the article; gave final approval of the version to be published; have agreed on the journal to which the article has been submitted; and agree to be accountable for all aspects of the work.

\section{Funding}

There is no funding to report.

\section{Disclosure}

The authors declare that they have no competing interests.

\section{References}

1. Pacella M, Gallo F, Gastaldi C, Ambruosi C, Carmignani G. Primary malignant melanoma of the bladder. Int J Urol. 2006;13:635-637. doi:10.1111/j.1442-2042.2006.01375.x

2. Venyo AKG. Melanoma of the urinary bladder: a review of the literature. Surg Res Pract. 2014;2:1-13. doi:10.1155/2014/605802

3. Barillaro F, Camilli M, Dessanti P, et al. Primary melanoma of the bladder: case report and review of the literature. ArchItal Urol Androl. 2018;30:224-226. doi:10.4081/aiua.2018.3.224

4. Bumbu GA, Berechet MC, Pop OL, et al. Primary malignant melanoma of the bladder - case report and literature overview. Rom $J$ Morphol Embryol. 2019;60:287-292. PMID: 31263858.

5. Karabulut YY, Erdogan S, Sayar H, Ergen A, Ertoy BD. Primary malignant melanoma of the urinary bladder: clinical, morphological, and molecular analysis of five cases. Melanoma Res. 2016;26 (6):616-624. doi:10.1097/CMR.0000000000000300

6. Kirigin M, Lež C, Šarčević B, et al. Primary malignant melanoma of the urinary bladder: case report. Acta Clin Croat. 2019;58:180-182. doi:10.20471/acc.2019.58.01.23

7. Korabiowska M, Fischer G, Steinacker A, Stachura J, Cordon-Cardo C, Brinck U. Cytokeratin positivity in paraffin-embedded malignant melanomas: comparative study of KL1, A4 and Lu5 antibodies. Anticancer Res. 2004;24(5B):3203-3207. PMID: 15510611.

8. Ainsworth AM, Clark WH, Mastrangelo M, Conger KB. Primary malignant melanoma of the urinary bladder. Cancer. 1976;37 (4):1928-1936. doi:10.1002/1097-0142(197604)37:4<1928::aidcncr2820370444>3.0.co; $2-\mathrm{w}$

9. Howard JH, Thompson JF, Mozzillo N. Metastasectomy for distant metastatic melanoma: analysis of data from the first multicenter selective lymphadenectomy trial (MSLT-I). Ann Surg Oncol. 2012;19:2547-2555. doi:10.1245/s10434-012-2398-z

10. Van Ahlen H, Nicolas V, Lenz W, et al. Primary melanoma of urinary bladder. Urology. 1992;40:550-554. doi:10.1016/0090-4295(92) 90414-r

11. Davies H, Bignell GR, Cox C, et al. Mutations of the BRAF gene in human cancer. Nature. 2002;417(6892):949-954. doi:10.1038/ nature 00766 .

12. Wheelock MC, Warren S. Leiomyosarcoma of the uterus. Ann Surg. 1942;116(6):882-890. doi:10.1097/00000658-194212000-00012

13. Ct SU, Prince CL. Melanoma of the bladder. J Urol. 1962;87:365367. doi:10.1016/s0022-5347(17)64965-6 
14. Willis AJ, Huang AH, Carroll P. Primary melanoma of the bladder: a case report and review. J Urol. 1980;123(2):278-281. doi:10.1016/ s0022-5347(17)55897-8

15. Anichkov NM, Nikonov AA. Primary malignant melanomas of the bladder. J Urol. 1982;128(4):813-815. doi:10.1016/s0022-5347(17) 53200-0

16. Ironside JW, Timperley WR, Madden JW, Royds JA, Taylor CB. Primary melanoma of the urinary bladder presenting with intracerebral metastases. Br J Urol. 1985;57(5):593-594. doi:10.1111/j.1464410x.1985.tb05880.x

17. Goldschmidt P, Py JM, Kostakopoulos A, Jacqmin D, Grosshans E, Bollack C. Primary malignant melanomas of the urinary bladder. $\mathrm{Br} J$ Urol. 1988;61(4):359. doi:10.1111/j.1464-410x.1988.tb13975.x

18. Philippe P, Volant A, Fournier G, Mangin P. Mélanome malin primitif de la vessie. A propos d'un cas [Primary malignant melanoma of the bladder. Apropos of a case]. J Urol (Paris). 1989;95(4):247-250.

19. Van Ahlen H, Nicolas V, Lenz W, Boldt I, Bockisch A, Vahlensieck W. Primary melanoma of urinary bladder. Urology. 1992;40(6):550 554. doi:10.1016/0090-4295(92)90414-r

20. Lund L, Storgård L, Noer H. Primary malignant melanoma of the urinary bladder. Case report. Scand J Urol Nephrol. 1992;26(2):205206. doi:10.1080/00365599.1992.11690458

21. Kojima T, Tanaka T, Yoshimi N, Mori H. Primary malignant melanoma of the urinary bladder. Arch Pathol Lab Med. 1992;116 (11):1213-1216. PMID: 1444751.

22. Lange-Welker U, Papadopoulos I, Wacker HH. Primary malignant melanoma of the bladder. A case report and literature review. Urol Int. 1993;50(4):226-228. doi:10.1159/000282490

23. Mourad WA, Mackay B, Ordonez NG, Ro JY, Swanson DA. Clear cell melanoma of the bladder. Ultrastruct Pathol. 1993;17(3-4):463468. doi:10.3109/01913129309027791

24. Niederberger CS, Lome LG. Primary malignant melanoma of urinary bladder. Urology. 1993;41(1):72-74. doi:10.1016/0090-4295(93) 90250-e

25. De Torres I, Fortuño MA, Raventos A, Tarragona J, Banus JM, Vidal MT. Primary malignant melanoma of the bladder: immunohistochemical study of a new case and review of the literature. J Urol. 1995;154 (2 Pt 1):525-527. [PMID: 7609125]. doi:10.1016/S0022-5347(01) 67094-0

26. Tainio HM, Kylmälä TM, Haapasalo HK. Primary malignant melanoma of the urinary bladder associated with widespread metastases. Scand J Urol Nephrol. 1999;33(6):406-407. doi:10.1080/ 003655999750017086

27. García Montes F, Lorenzo Gómez MF, Boyd J. Existe el melanoma primario de vejiga? [Does primary melanoma of the bladder exist?]. Actas Urol Esp. 2000;24(5):433-436. doi:10.1016/s0210-4806(00) 72477-6

28. Khalbuss WE, Hossain M, Elhosseiny A. Primary malignant melanoma of the urinary bladder diagnosed by urine cytology: a case report. Acta Cytol. 2001;45(4):631-635. doi:10.1159/000327878
29. Hsu T, Hsu Y. Primary malignant melanoma of the urinary bladder. Tzu Chi Med J. 2002;14(4):253-256. doi:10.6440/ TZUCMJ.200208.0253

30. Baudet C, Shell M, Bergeron C, et al. Mélanome vésical chez une fillette de 7 ans [Bladder melanoma in a 7-year-old girl]. Prog Urol. 2005;15(1):67-70. PMID: 15822396.

31. Sundersingh S, Majhi U, Narayanaswamy K, Balasubramanian S. Primary spindle cell melanoma of the urinary bladder. Indian $J$ Pathol Microbiol. 2011;54(2):422-424. doi:10.4103/03774929.81612

32. El Ammari JE, Ahallal Y, El Fassi MJ, Farih MH. Primary malignant melanoma of the urinary bladder. Case Rep Urol. 2011;2011:932973. doi:10.1155/2011/932973

33. Truong H, Sundi D, Sopko N, et al. Report of primary recurrent malignant melanoma of the urinary bladder. Urol Case Rep. 2013;1 (1):2-4. doi:10.1016/j.eucr.2013.10.002

34. Sayar H, Erdogan S, Adamhasan F, Gurbuz E, Inci MF. Malignant melanoma of the bladder: a case report. Can Urol Assoc J. 2014;8(12):E54-6. doi:10.5489/cuaj.1242

35. Khan M, O’Kane D, Du Plessis J, Hoag N, Lawrentschuk N. Primary malignant melanoma of the urinary bladder and ureter. Can J Urol. 2016;23(1):8171-8175. PMID: 26892061.

36. Laudisio A, Giua R, Papalia R, Taffon C, Muto G, Antonelli Incalzi R. An unusual cause of hematuria: primary bladder melanoma in an older man. J Am Geriatr Soc. 2016;64(10):e122-e123. doi:10.1111/ jgs. 14407

37. Otto T, Barski D, Bug R. Das maligne melanom der Harnblase [Malignant melanoma of the urinary bladder]. Urologe A. 2017;56 (7):861-863. doi:10.1007/s00120-017-0421-5

38. Buscarini M, Conforti C, Incalzi RA, et al. Primary malignant melanoma of the bladder. Skinmed. 2017;15(5):395-397. PMID: 29139373.

39. Osorio E, Orozco R, Argueta V. Melanoma primario de vejiga urinaria: presentación de caso [Primary melanoma of the bladder. A case report]. Rev Esp Patol. 2018;51(4):244-247. doi:10.1016/j. patol.2017.12.001

40. Chaus FM, Craig M, Bracamonte E, Sundararajan S, Lee BR. Primary malignant melanoma of the bladder treated by robotic partial cystectomy and immunotherapy. J Endourol Case Rep. 2019;5 (4):151-153. doi:10.1089/cren.2019.0031

41. Rubio GJM, Gomez GE, Valero RJ, et al. Primary melanoma of the bladder at puerperium: case report. Int Arch Urol Complic. 2020;6:073. doi:10.23937/2469-5742/1510073

42. Rapisarda S, Bada M, Polara A, et al. Conservative management of primary malignant melanoma of the bladder: a case report. $J$ Med Case Rep. 2021;15(1):39. doi:10.1186/s13256-020-02602-7

43. Snajdar E, Ajo AR, Rosen K, et al. Primary malignant melanoma of the urinary bladder. Cureus. 2021;13(3):e14067. doi:10.7759/ cureus. 14067
Research and Reports in Urology

\section{Publish your work in this journal}

Research and Reports in Urology is an international, peer-reviewed, open access journal publishing original research, reports, editorials, reviews and commentaries on all aspects of adult and pediatric urology in the clinic and laboratory including the following topics: Pathology, pathophysiology of urological disease; Investigation and treatment of urological disease; Pharmacology of drugs used for the treatment of urological disease. The manuscript management system is completely online and includes a very quick and fair peer-review system, which is all easy to use. Visit http://www.dovepress.com/ testimonials.php to read real quotes from published authors. 